\title{
Improving the nutritional status of school children through the formation of a group of children caring for nutrition in SD Az- Zakiyah Islamic School
}

\author{
Ernawati Nasution ${ }^{1 *}$, Fitri Ardiani ${ }^{1}$, Etti Sudaryati ${ }^{1}$ \\ ${ }^{1}$ Fakultas Kesehatan Masyarakat Universitas Sumatera Utara Medan \\ Email: "nasutionernawati38@yahoo.com
}

\begin{abstract}
This service activity is a training for school children to care about their food consumption and nutritional status. This service activity carried out at SD Az-Zakiyah Islamic School Medan aims to provide understanding to school children about healthy, nutritious, and balanced food, as well as weight and height measurement skills. The methods used are lectures, practice of measuring body weight and height using microtoas and digital scales, and the practice of introducing food ingredients that contain nutrients using a food model. The $t$ test results showed that there was a significant difference $(\mathrm{p}=0.005)$ in children's knowledge before and after providing information. This shows that this training provides increased knowledge of school children. It is hoped that the training participants will later become nutritional ambassadors who can disseminate information about healthy, nutritious, and balanced food and the importance of monitoring nutritional status from an early age to their friends, especially at school and in the environment around their homes in an effort to improve nutritional status in school children. In addition, I hope this program will be sustainable and will raise awareness among school foundations and health centers to support this activity which has been initiated in college.
\end{abstract}

\section{Keywords : ambasador, nutrition}

\begin{abstract}
Abstrak
Kegiatan pengabdian ini merupakan pelatihan kepada anak sekolah untuk peduli terhadap konsumsi makan mereka dan status gizi. Kegiatan pengabdian ini dilaksanakan di SD Az- Zakiyah Islamic School Medan bertujuan untuk memberikan pemahaman kepada anak sekolah tentang makanan sehat bergizi dan seimbang, serta keterampilan pengukuran berat badan (BB) dan tinggi badan (TB). Metode yang dilakukan adalah ceramah, praktek pengukuran TB dan BB dengan menggunakan mikrotoa dan timbangan digital, dan praktek pengenalan terhadap bahan-bahan makanan yang mengandung zat gizi dengan menggunakan food model. Hasil Uji t test menunjukkan bahwa ada perbedaan yang signifikan $(\mathrm{p}=0,005)$ pada pengetahuan anak sebelum dan sesudah pemberian materi. Hal ini menunjukkan bahwa pelatihan ini memberikan peningkatan pengetahuan anak sekolah. Diharapkan kepada para peserta pelatihan nantinya dapat menjadi duta gizi yang dapat menyebarluaskan informasi tentang makanan sehat, bergizi, dan seimbang serta pentingnya pemantauan status gizi sejak dini kepada teman-temannya khususnya di sekolah dan di lingkungan sekitar rumah mereka dalam upaya meningkatkan status gizi pada anak usia sekolah. Selain itu, semoga program ini berkelanjutan dan membuka kesadaran pihak yayasan sekolah dan puskesmas agar mendukung kegiatan ini yang telah diawali dari perguruan tinggi.
\end{abstract}

Kata Kunci : duta, gizi

\section{PENDAhULUAN}

Kualitas bangsa di masa depan ditentukan oleh kualitas anak-anak saat ini. Anak sekolah merupakan salah satu generasi penerus bangsa yang harus diperhatikan kesehatan dan status gizinya. Masih tingginya masalah gizi pada anak sekolah seperti masalah gizi kurang, stunting, dan gizi lebih menjadi perhatian Indonesia di dalam upaya memperbaiki dan meningkatkan status gizi dan kesehatan pada 
kelompok ini. Satus gizi anak sekolah merupakan salah satu ukuran anak sekolah dinyatakan sehat. Status gizi yang buruk merupakan keadaan yang menggambarkan terhambatnya pertumbuhan. Stunting merupakan kegagalan untuk mencapai pertumbuhan optimal yang disebabkan oleh keadaan gizi kurang yang berlangsung dalam waktu yang lama. Stunting pada anak, selain disebabkan oleh defisiensi zat gizi makro, juga berhubungan dengan defisiensi seng ( $\mathrm{Zn})$. Seng ( $\mathrm{Zn})$ adalah mineral esensial yang berperan dalam sintesis, sekresi, dankontrol hormon pertumbuhan (Growth Hormon). Rendahnya sintesis hormon pertumbuhan dapat menghambat pertumbuhan linier dan didugamenyebabkan kondisi stunting pada masabalita (Hidayati, Hadi, \& Kumara, 2011). Permasalahan gizi yang terjadi pada anak sekolah ini akan menghambat pencapaian prestasi anak, sehingga dibutuhkan suatu upaya bersama untuk mengatasi permasalahan tersebut. Masalah gizi pada anak usia sekolah dapat menyebabkan rendahnya kualiatas tingkat pendidikan, tingginya angka absensi dan tingginya angka putus sekolah (WKPG, 1998 dalam Sulastri, 2012). Hasil Riset kesehatan Dasar menunjukkan ada penurunan angka stunting dari 37,2 persen pada Riskesdas tahun 2013 menjadi 30,8 persen pada Riskesdas (2018). Persentase ini termasuk tinggi, karena mengacu dari data WHO yang prevalensinya harus kurang dari 20 persen. Prevalensi stunting di Sumatera Utara sebesar 43,2\% dengan kategori sangat pendek sebesar $20,6 \%$ dan pendek sebesar 22,6\% (Depkes, 2010). Masalah kesehatan masyarakat dianggap berat bila prevalensi sangat pendek sebesar 30-39\% dan serius bila prevalensi pendek > 40\% (WHO, 2010).

Berbagai upaya sudah dilakukan oleh pemerintah untuk menanggulangi masalah gizi pada anak sekolah. Namun masih sedikit sekali upaya ke arah promotif dan pencegahan, terutama dengan mengikutsertakan anak sendiri di dalam upaya tersebut. Padahal anak dapat merupakan objek dan sekaligus subjek di dalam upaya untuk mencegah masalah gizi pada dirinya maupun pada kelompok usia mereka. Pelatihan dalam pengabdian ini dilakukan dengan metode ceramah tentang makanan sehat bergizi seimbang dan jajanan yang sehat, praktek pengukuran antropometri (berat badan dan tinggi badan) dan pembentukan kelompok anak peduli gizi.

Pengetahuan tentang gizi yang merupakan salah satu faktor yang mempengaruhi status gizi seseorang. Rendahnya pengetahuan tersebut akan mengurangi kemampuan seseorang untuk menerapkan informasi gizi dalam kehidupan sehari-hari. Maka memberikan pendidikan gizi sedini mungkin merupakan salah satu cara untuk meningkatkan pengetahuan seseorang. Pendidikan gizi ini dapat diberikan melalui penyuluhan, pemberian poster, leaflet atau booklet pada anak sekolah (Machfoedz dan Suryani, 2007).

Berdasarkan survei pendahuluan diketahui bahwa anak-anak sekolah di SD Az- Zakiyah Islamic School tidak memahami pentingnya kesehatan dan status gizi, dan mempunyai kebiasaan makan jajan yang salah, sehingga masih banyak anak yang mengalami masalah gizi (gizi kurang, stunting, dan gizi lebih) dan kurangnya pemahaman anak terhadap makanan seimbang dan jajanan sehat bergizi. Selain itu belum adanya kelompok anak yang peduli terhadap gizi di sekolah yang akan menjadi agent bagi teman sebayanya dalam upaya meningkatkan status gizi pada anak sekolah.

Maka melalui pengabdian ini akan dilakukan pembentukan kelompok anak peduli gizi yang merupakan kumpulan anak-anak yang sudah dilatih untuk peduli terhadap status gizi dan konsumsi makan mereka sehari-hari. Pembentukan kelompok ini diharapkan dapat mengimbaskan perilaku yang baik kepada teman-temannya yang lain.

\section{METODE PELAKSANAAN}

Metode yang dilakukan dalam pengabdian ini adalah ceramah tentang makanan seimbang dan jajanan sehat dan bergizi, praktek pengukuran antropometri (berat badan dan tinggi badan) dengan menggunakan mikrotoa dan timbangan digital, dan praktek pengenalan terhadap bahan-bahan makanan yang mengandung zat gizi dengan menggunakan food model. Pengabdian ini dilakukan dalam bentuk pelatihan pada siswa di SD Az- Zakiyah Islamic School Medan. Analisa statistik dilakukan untuk melihat perbedaan pengetahuan anak sekolah sebelum dan sesudah informasi diberikan dengan menggunakan Uji t test.

\section{HASIL DAN PEMBAHASAN}


Kegiatan pelatihan ini diawali dengan pretest dengan pemberian kuesioner tentang pengetahuan anak dalam hal makanan seimbang dan bergizi. Kemudian dilanjutkan dengan pemberian materi tentang tentang makanan seimbang, jajanan sehat bergizi, dan pematauan pertumbuhan (berat badan dan tinggi badan) tentang makanan seimbang, jajanan sehat bergizi. Setelah pemberian materi dilakukan tanya jawab. Setelah pemberian materi dilanjutkan dengan praktek penimbangan berat badan dan pengukuran tinggi badan dan pengenalan terhadap bahan-bahan makanan yang mengandung zat gizi karbohidrat, protein, lemak, vitamin dan mineral dengan menggunakan food model. Pada sesi praktek ini anak-anak dibagi atas dua kelompok. Kelompok pertama adalah anak-anak melakukan praktek pengukuran tinggi badan dengan menggunakan mikrotoa dan penimbangan berat badan dengan menggunakan timbangan digital. Sedangkan anak-anak kelompok kedua melakukan kegiatan pengenalan terhadap sumbersumber zat gizi dari bahan makanan dengan menggunakan food model. Setelah kegiatan praktek dilakukan, sebelum acara pelatihan ditutup dilakukan post-test terhadap pengetahuan anak dan dilanjutkan dengan pemberian selempang bertuliskan "Anak Peduli Gizi” sebagai tanda mereka adalah duta anak peduli gizi yang harapannya akan dapat mengimbaskan apa yang telah mereka ketahui ssetelah mengikuti acara pelatihan ini kepada teman-temannya yang lain.

Berikut adalah beberapa dokumentasi pelaksanaan kegiatan pengabdian kepada masyarakat:

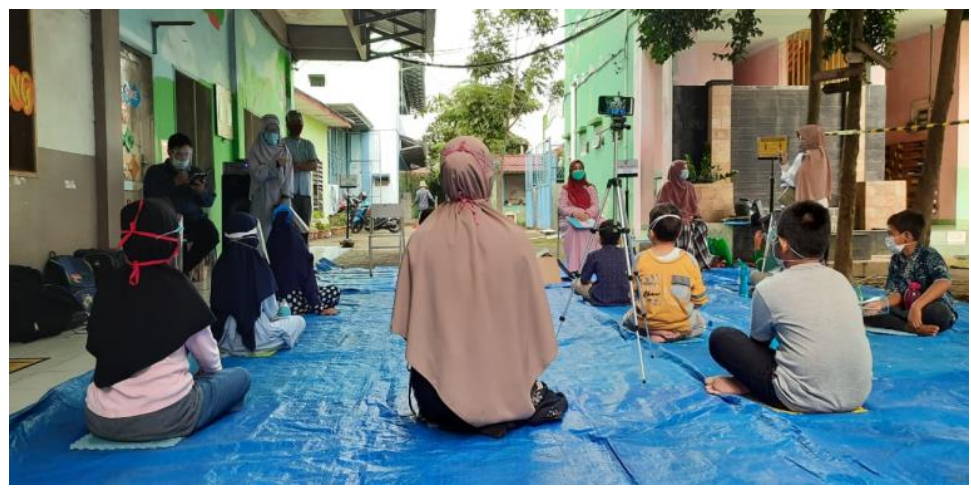

Gambar 3.1. Pembukaan Acara Pelatihan Anak Peduli Gizi

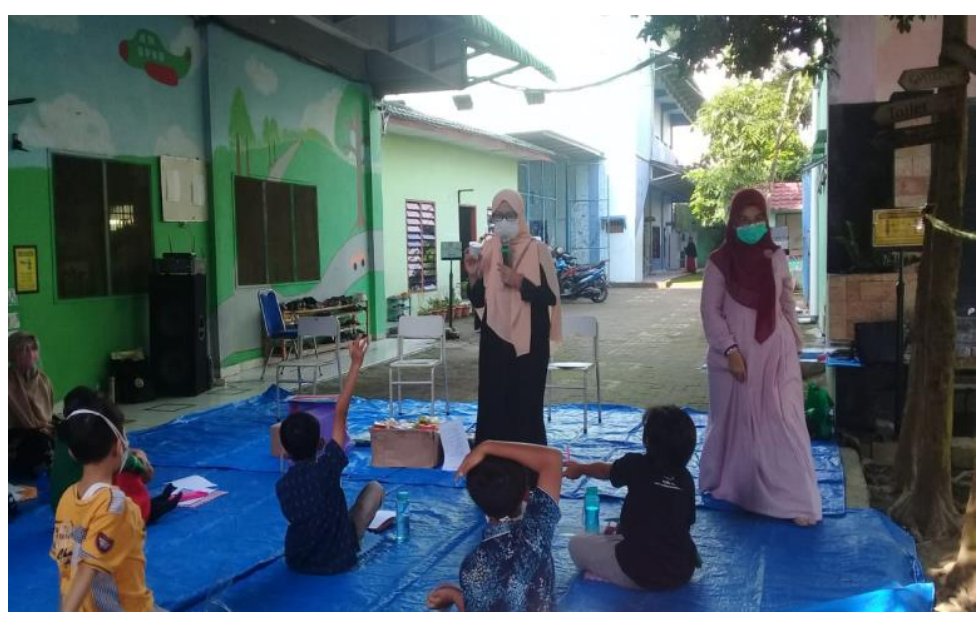

Gambar 3.2 Pemberian materi pelatihan dan tanya jawab 

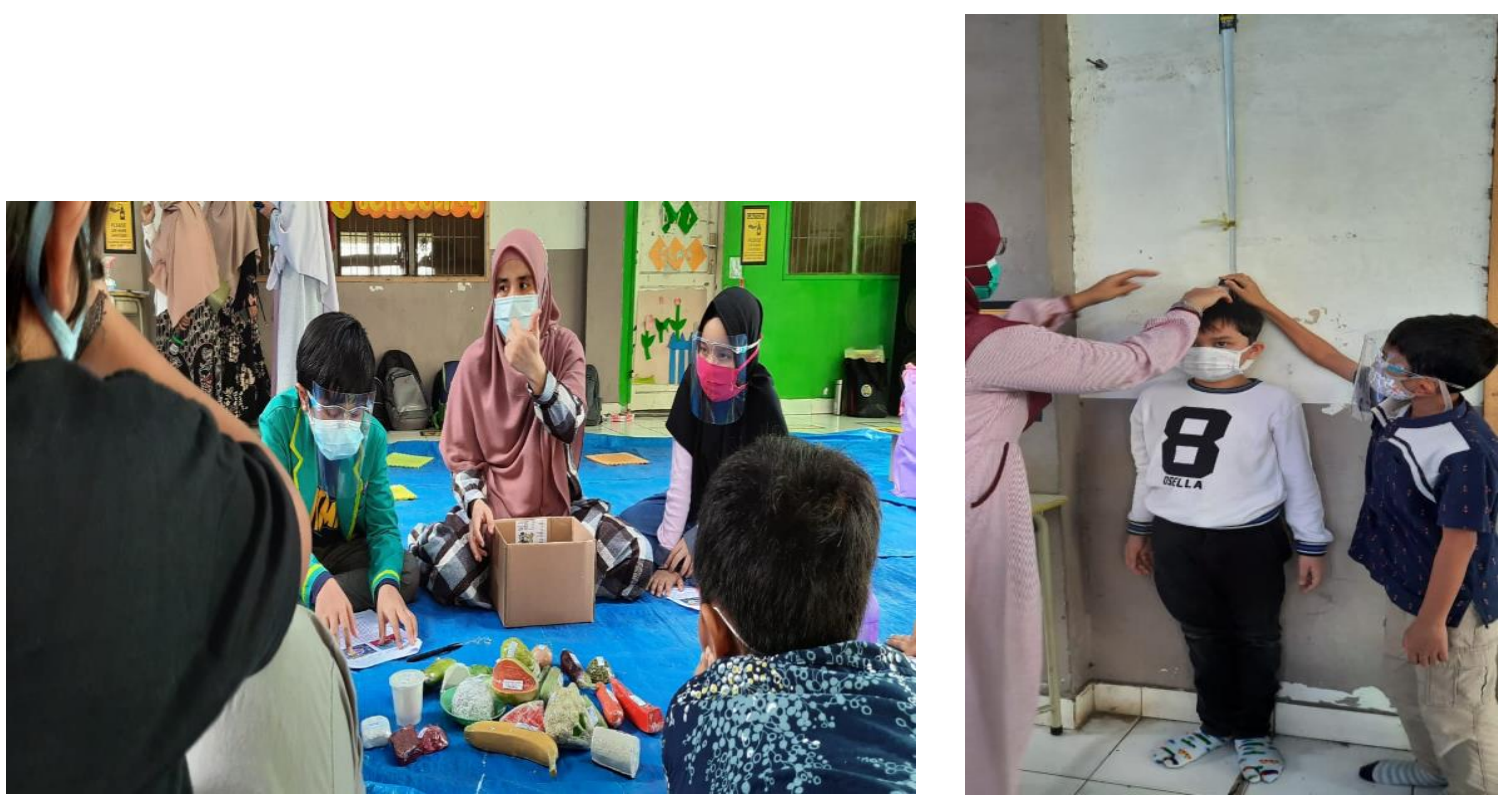

Gambar 3.3. Praktek Penyusunan menu seimbang

Gambar 3.4. Praktek pengukuran TB

Hasil analisis terhadap pengetahuan anak sekolah dengan menggunakan Uji t test menunjukkan bahwa ada perbedaan yang signifikan $(\mathrm{p}=0,005)$ pada pengetahuan anak sebelum dan sesudah pemberian materi tentang makanan bergizi dan seimbang. Hal ini menunjukkan bahwa pelatihan ini memberikan peningkatan pemahaman dan pengetahuan anak sekolah tentang makanan bergizi dan seimbang. Secara jelas dapat dilihat pada Tabel 1 dan Tabel 2.

Tabel 1. Nilai rata pengetahuan siswa sebelum dan sesudah informasi diberikan

\begin{tabular}{|ll|r|r|r|l|}
\hline & & & & \\
& & Mean & $\mathrm{N}$ & Std. Deviation & Std. Error Mean \\
\hline Pair 1 & Pre Test & 6,2000 & 15 & 1,56753 &, 40473 \\
& Post Test & 7,8000 & 15 & 1,42428 &, 36775 \\
\hline
\end{tabular}

Tabel 2. Hasil Uji t test terhadap pengetahuan anak sebelum dan sesudah informasi diberikan

\begin{tabular}{|ll|r|r|r|}
\hline & & $\mathrm{N}$ & Correlation & \multicolumn{1}{c|}{ Sig. } \\
\hline Pair 1 & PRE TEST \& POST TEST & 15 &, 243 &, 383 \\
\hline
\end{tabular}

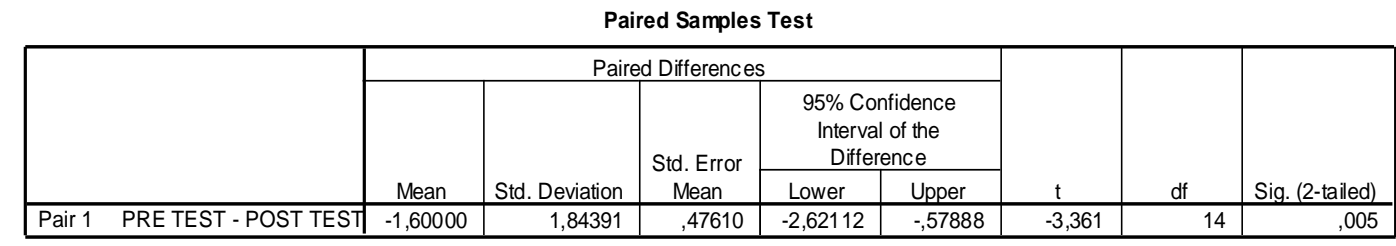

Hasil uji statistik dalam pengabdian ini sama dengan hasil penelitian yang dilakukan oleh Nuryanto, Pramono, Paruhita, dan Muis (2014), yang menjelaskan bahwa ada peningkatan skor pengetahuan dan sikap anak sekolah setelah pendidikan gizi diberikan. Penelitian yang dilakukan Suliastutik, Ariyanti, dan Suswita (2018), juga menyatakan hal yang sama bahwa pemberian edukasi sangat mempengaruhi tingkat pengetahuan dan tingkat konsumsi. 


\section{KESIMPULAN}

Berdasarkan kegiatan pengabdian yang telah dilakukan dapat disimpulkan bahwa pemberian informasi tentang makanan sehat, bergizi, dan seimbang melalui pelatihan dapat meningkatkan pengetahuan anak sekolah dan pemahaman terhadap pengukuran berat badan dan tinggi badan.

Diharapkan kepada para peserta (siswa SD) pelatihan nantinya akan menjadi duta gizi yang dapat menyebarluaskan informasi tentang makanan sehat, bergizi, dan seimbang serta pentingnya pemantauan status gizi sejak dini.

\section{UCAPAN TERIMAKASIH}

Artikel ini merupakan salah satu hasil dari Program Pengabdian kepada Masyarakat yang Dibiayai oleh dana NON PNBP Universitas Sumatera Utara dengan nomor 287/UN5.2.3.2.1/PPM/2020. Oleh karena itu, diucapkan terima kasih kepada Rektor USU dan LPPM USU yang telah memberikan dana pengabdian tahun 2020 Skema Profesor mengabdi. Terima kasih juga kepada Mitra pada kegiatan pengabdian ini.

\section{DAFTAR PUSTAKA}

Depkes RI. 2010. Profil Kesehatan Indonesia 2010. Jakarta :Departemen Kesehatan Republik Indonesia.

Hidayati, L., Hadi, H. \& Kumara, A. 2011. “Kekurangan Energi dan Zat Gizi Merupakan Faktor Risiko Kejadian Stunted pada Anak Usia 1-3 Tahun yang Tinggal di Wilayah Kumuh Perkotaan Surakarta”. Jurnal Kesehatan 3.

Kementerian Kesehatan RI. 2018. Laporan Hasil Riset Kesehatan Dasar (Riskesdas) tahun 2018. Jakarta. Badan Penelitian dan Pengembangan Kesehatan.

Machfoedz I dan Suryani S. 2007. Pendidikan Kesehatan Bagian Dari Promosi Kesehatan, Fitramaya, Yogyakarta, p.8-73

Nuryanto, Pramono Adriyan, Puruhita Niken, Muis Siti Fatimah. 2014. Pengaruh Pendidikan Gizi Terhadap Pengetahuan Dan Sikap Tentang Gizi Anak Sekolah Dasar. Jurnal Gizi Indonesia (ISSN : 1858-4942) Vol. 3, No. 1, Desember 2014: 32-36. https://media.neliti.com/media/publications/80662-ID-pengaruh-pendidikan-gizi-terhadappenget.pdf. Diunduh pada tanggal 20 November 2020.

Suhardjo. 2003. Berbagai Cara Pendidikan Gizi. Bumi Aksara, Jakarta.

Sulistiastutik, Ariyanti Nur Ayu, Suwita I Komang, 2018. Edukasi, Tingkat Pengetahuan, Tingkat Konsumsi Zat Gizi Dan Kadar Hemoglobin Anak Sekolah Dasar. Jurnal Informasi Kesehatan Indonesia Vol. 4 No. 1. Mei 2018 33-42.

https://doi.org/10.31290/jiki.v(4)i(1)y(2018).page:33-42. Diunduh pada tanggal 20 November 2020. 